\title{
An Inquiry into the Perception and Use of Services Provided by Teachers' Resource Centres by Secondary School Teachers in Biharamulo District, Tanzania
}

\author{
Logatus Logation $^{1} \quad$ Joyce G. Mbepera ${ }^{2}$ \\ 1. Doctorate Student, Faculty of Education. The Open University of Tanzania \\ 2. Lecturer, College of Education, University of Dodoma
}

\begin{abstract}
This study intended to examine the perception and use of services provided by teachers' resource centres (TRCs) by secondary school teachers in Biharamulo District. Specifically, the study aimed to assess secondary school teachers' perceptions of TRCs in Biharamulo District; establish the role of secondary school heads in promoting access and use of TRCs in Biharamulo District by teachers under their supervision; and identify factors that hinder the attendance of secondary school teachers at the TRCs in Biharamulo District. The study involved 76 participants, being 10 heads of schools, 3 TRCs coordinators and 63 teachers. The study collected quantitative data by questionnaire and qualitative data by focus group discussion and interview. The study found that teachers perceive that TRCs improve their teaching effectiveness despite being intended for primary school teachers. On the other hand, secondary school heads seldom remind teachers to attend TRCs. Secondary school teachers' absence from TRCs is attributed to the lack of fund, the lack of modern resources at the centres, the long distance between the working stations and TRCs, and the lack of individual teacher's commitments. The study has significant implications for school heads, teachers, and the Ministry of Education, Science and Technology in reviving the regular use of TRCs for professional development. The study concluded that heads of schools did not insist teachers' attendance at TRCs because they do not recognize their role to inspire teachers to attend TRCs regularly. The study recommends seasonal training to heads of secondary schools regarding promoting teachers' attendance at TRCs under their supervision.
\end{abstract}

Keywords:Teachers' resource centres (TRCs), Heads of schools, TRCs accessibility and Secondary school teachers

DOI: $10.7176 / \mathrm{JEP} / 12-19-02$

Publication date:July $31^{\text {st }} 2021$

\section{INTRODUCTION}

Teachers' Resource Centres (TRCs) are places where teachers gather to discuss matters related to their work and where teaching and learning resources are housed (Knamiller, Jain, Khatete, Gibbs, Welford, Fairhurst \& Wiegand, 1999). That is, they provide a meeting point for teachers and other education stakeholders.

Historically, Teachers' Resource Centres (TRCs) were first established in Britain between the late 1950s and early 1960s to help teachers develop as professionals and improve the teaching and learning process (Knamiller et al., 1999). In the late 1960s and early 1970s, a significant wave of educational reform in Asia and Latin America brought TRCs to the forefront as an innovative strategy towards improving teaching and learning. After this period of reform, TRCs continued to operate in some countries (Giordano, 2008). At the end of 1970s, the TRC concept began to be exported to developing countries (Mushi, 2003).

In Tanzania, the first TRC was established at Kleruu Teachers' College in 1972 with financial support from Denmark's government. In 1986 the Ministry of Education and Culture issued a directive to establish TRCs in every region and district (Qvist \& Omar, 1996). By the year 1999, a total of 283 TRCs were already established in Tanzania Mainland and 9 in Zanzibar (Binde, 1999). By the year 2018, three TRCs were built in Biharamulo District: Nyakahura, Rubondo and Kikomakoma (BDC, 2018).

The TRCs have come to be regarded as an effective way of supporting teachers' professional development and providing an opportunity to access organized educational resources (Knamiller et al., 1999). Giordano (2008) maintains that TRCs are intended to deliver professional development activities such as in-service training that support teachers' instructions.

According to Koda (2012), TRCs bring about significant educational reforms and professional development by helping teachers to identify problems and formulate solutions to such problems. They are the most important school curriculum bases in connecting curriculum development and teacher education to give professional support to staff and learners (Msuya, 2015). Further, teachers' resource centres provide a forum for teachers to discuss, network, exchange ideas, make teaching aids, seek advice, and communicate with other professionals about teaching and learning (Msuya, 2015). In a nutshell, teachers' resource centres are intended to help teachers deal with the day-to-day challenges and obstacles of globalization and changes in education.

Nonetheless, researchers (Giordano, 2008; Knamiller et al., 1999; Koda, 2006; Mirambo, 2007; Mushi, 
2003; Qvist \& Omar, 1996; Sabaya, 2011) show that TRCs have not met these ideal objectives in many countries. That is, teachers continue to face challenges such as designing poor teaching aids and using old methods of delivering messages to students despite of having TRCs around. Ndikumwami (2013) observed that many primary school teachers work for more than fifteen years without any in-service training to improve their skills and knowledge in Tanzania despite of TRCs presence. Furthermore, Sumra and Rajani (2006) found that most teachers teach by using rote techniques-requiring students to copy or take notes on the white/blackboard. This implies that these teachers lack new strategies to facilitate their lessons and eventually affect students' academic performance.

Several reasons have been given for the failure of these centres to meet their ultimate goals. Knamiller et al. (1999), who researched in Zambia and Kenya, found that many teachers did not access services provided by TRCs in their areas for reasons such as long distance to centres and lack of motivation.

Hardman, Abrishamian, Chediel and Tibuhinda (2009) studied TRCs in Tanzania and reported inadequate and or un-coordinated in-services provided by the centres. Koda (2006) observed that teachers do not use resource centres frequently because they are denied permission by their supervisors to attend the programmes conducted in TRCs due to a shortage of staff in their schools.

As shown, studies have been done about the low accessibilities offered by TRCs inside and outside Tanzania. However, studies in Tanzania have focused on the use of TRCs by primary school teachers. This left a knowledge gap on how secondary school teachers access and use TRCs services. The present study particularly examined:

(i) Secondary school teachers' perceptions of TRCs in Biharamulo District.

(ii) The role of secondary school heads in facilitating the access and use of TRCs in Biharamulo District by teachers under their supervision.

(iii) Factor(s) that hinder the attendance of secondary school teachers at TRCs in Biharamulo District.

\subsection{Significance of the Study}

This study is expected to contribute to the literature in three distinct ways: theoretically, practically, and in policy formulation. Theoretically, the study adds new knowledge of TRCs' use and access. It highlights the role of heads of schools in helping centres meet their mission and vision which will improve the delivery of quality instructions in classrooms. Second, the study helps policy makers to apply the Attribution Theory in education settings to see what could be done in order to improve TRCs accessibility effectively. Particularly by setting an environment under which the attributes from policy makers facilitate emotional and behavioral responses for teachers to access and use TRCs services.

Third, the study gives insights into how the TRCs can be better used by the Ministry of Education, Science and Technology to improve secondary school teachers' career development. This, in turn, will improve teachers' teaching ability thereby improving the teaching and learning process.

\section{LITERATURE REVIEW}

\subsection{Theoretical framework}

This study was guided by the Attribution Theory by Weiner (1972). Weiner's Attribution Theory assumes that people try to determine why people do what they do. That is, people interpret causes to an event or behaviour and make attributes. The theory holds that attributions for these behaviours and outcomes ultimately help to shape emotional and behavioural responses. Weiner focused his Attribution Theory on achievement and at last identified ability, effort, task difficulty, and luck as the most important factors affecting attributions for achievement. The Attribution Theory involves three stages: behaviour must be observed, behaviour must be determined to be intentional, and behaviour must be attributed to internal or external causes.

For the purpose of this study, heads of schools must observe teachers' teaching ability, effort, commitments as well as subject mastery. School heads must interpret causes behind the ways teachers teach their students to make necessary attributions for improved instruction delivery. In this case, sharpening teachers' perceptions on TRCs services and encouraging the use of TRCs is vital to enable teachers to acquire requisite skills and knowledge, use the teaching and learning resources, and update their careers, thus improving the delivery of quality instructions.

\subsection{Teachers resource centres and professional development}

Teachers' professional development entails processes and activities designed to promote teachers' professional knowledge, skills, and attitudes of teachers to improve teachers' attitudes and pupils' learning (Guskey, 2000). Professional development in education aims to build and transform teachers' knowledge to achieve excellence in teaching (Compoy, 1997). Teachers' professional development should be effective and successful to enhance students' learning, resulting in quality education in any country. 
Gaible and Burns (2005) argue that teacher professional development is a tool that policymakers use to convey broad visions, disseminate critical information, and guide teachers. Therefore, staff professional development is fundamental to promote teachers' development in several areas including technology, teaching methodology, and subject mastery. This is supported by Hassel (1999), who considers professional development as a process of improving staff skills and competencies needed to produce outstanding educational results for students. Considering professional development essential in schools, Pollard and Tann (1993) assert that for the government to maintain a high-quality education, teachers' professional development and learning should never stop.

Teachers' resource centres promote collaboration among schools and teachers, co-operation among education professionals and encourage more autonomy and professionalism (Giordano, 2008). Ribchester and Edwards (1998), Darcos (2003), and De Grauwe and Carron (2001) say that such collaboration enables teachers from rural schools and those from urban schools to perform assigned activities better than in the absence of such a co-operation. Hence, the reviewed literature inadequately informs the role of school heads in fostering teachers' professional development through the regular use of TRCs.

\subsection{Teachers' perceptions of TRCs}

Various scholars (Kisuda, 2005; Kimaro, 2005; Koda, 2006; Mirambo, 2007) found that most teachers perceive TRCs lacking enough resources to develop their careers. They add that most teachers view TRCs being less useful because they operate under inadequate modern resources. In Zambia, Knamiller et al (1999) revealed that most teachers perceive TRCs being under used and less important for career development. To the contrary, Hengerezi (2016) and Giordano (2008) found out that most teachers in Tanzania, Nepal and Kenya considered TRCs useful in improving their performance. The contradiction in the literature brings about an information gap.

\subsection{The role of heads of schools in promoting the TRCs' access and use}

A study conducted by Giordano (2008) found out that heads of schools encouraged teachers to find new and effective teaching methods. When stimulated, teachers from different schools may decide to meet monthly to share their innovations and work together on education projects (Richards, 1996). Sharing knowledge and information quickly diffuse innovations among teachers of different schools (Smith \& Wohlstetter, 2001). As seen, the reviewed literature inadequately informs on how school heads enhance teachers' attendance at the TRCs. Therefore, very little is still known regarding on how school heads improve teachers' attendance at TRCs. This information gap calls for further studies regarding how school heads enhance teachers' attendance at TRCs in the district.

\subsection{Factors that hinder the attendance of secondary school teachers at TRCs}

Studies such as Khan (2015) and Knamiller et al. (1999) found out that most teachers did not attend at the TRCs for their professional development. A study conducted by Temu, Malmberg and Lindhe (2004) found that the average book borrowing from TRCs in Tanzania is 18 book borrowers per month and an average of 16 readers per week. They added that TRCs libraries could accommodate 14 readers while seminar/workshop halls could accommodate up to an average of 37 participants at a time. This indicates a very poor teachers' attendance at TRCs in the country. However, the aforementioned literature inadequately states the reasons for teachers' absence from TRCs.

With regard to factors hindering TRCs' accessibility in Tanzania, Koda (2006) identified unavailability of learning and teaching materials, shortage of readings in libraries, insufficient funds and distant locations of TRCs. However, as geographical, economic and cultural conditions are different across Tanzania districts, the present study focused on examining the factors hindering the attendance and use of TRCs in Biharamulo District, which have not been established.

\subsection{The Conceptual Framework}

The roles played by secondary school heads influence TRCs accessibility in the district. These roles may include encouraging teachers, inspiring teachers, ensuring the borrowing of textbooks and reference books from the TRCs, providing time on the school calendar/timetable to visit TRCs, organising study trips to TRCs and encouraging teachers to acquire and share skills and knowledge at TRCs. Furthermore, teachers' perceptions of TRCs enable the presence or absence of teachers from TRCs. For instance, the perception that TRCs operate weakly makes teachers hesitate to attend at TRCs. In contrast, the perception that TRCs improve teachers' teaching effectiveness may increase teachers' attendance at TRCs. In addition, the security of the government's employment and satisfaction with their own levels of knowledge hindered teachers from attending at TRCs. Figure 1 shows the conceptual framework which guided the study. 


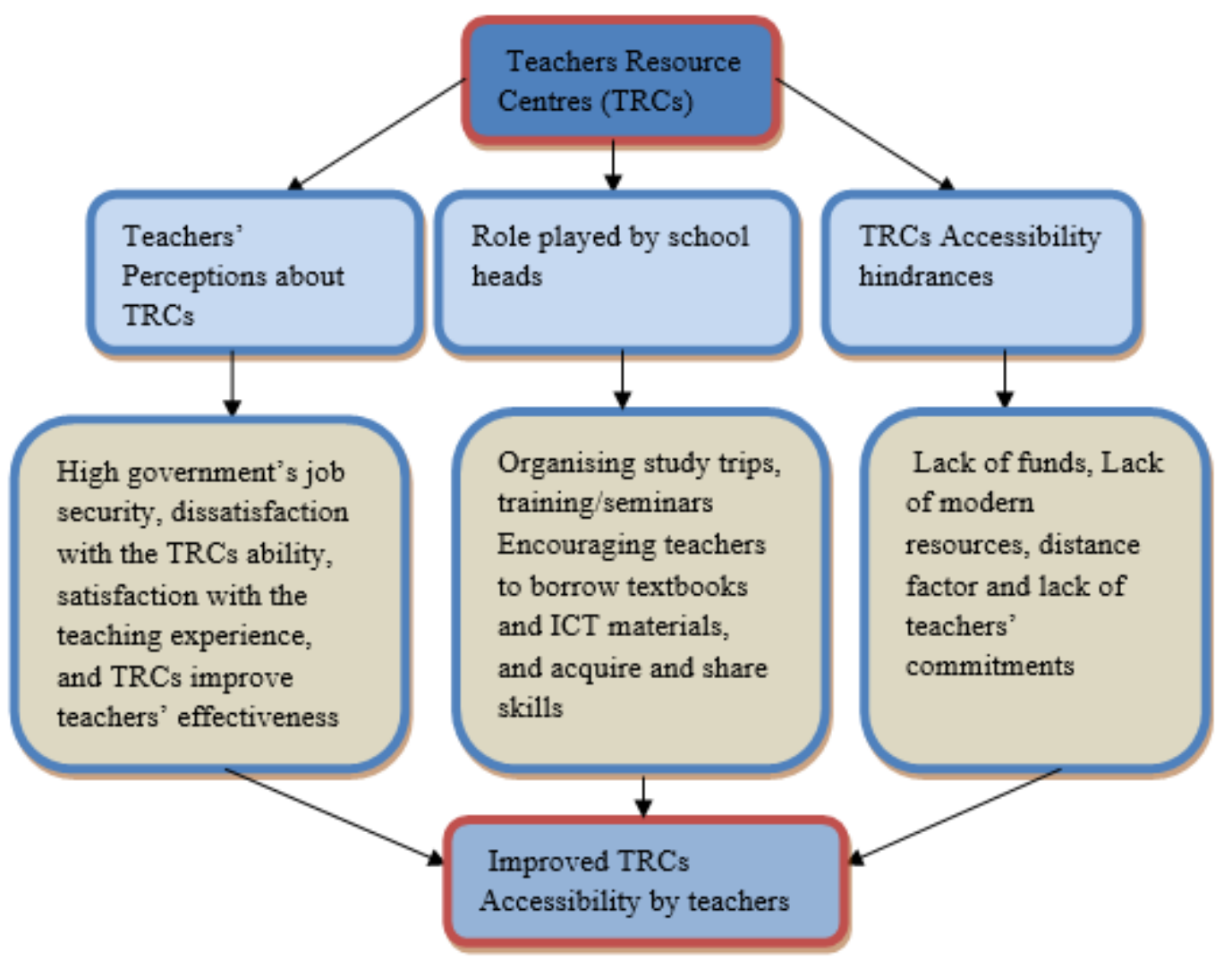

Figure 1: Conceptual Framework (Adapted and modified from Koda, 2012)

As the conceptual framework shows, regular teachers' attendance at TRCs is hindered by lack of funds, lack of school heads' motivation and inspiration, a long distance from TRCs to teachers' working stations, and the lack of teachers' commitments. Therefore, TRCs accessibility depends on teachers' perceptions of TRCs, the role played by school heads, and the aforementioned factors hindering teachers from attending TRCs.

\section{METHODOLOGY}

This study employed a concurrent triangulation design. A mixed methods approach was used. The target population for the study was 651 respondents consisting of 18 heads of schools, 3 TRCs coordinators and 630 teachers. Systematic random sampling was used to select teachers whereas every tenth teacher was selected. The purposive sampling was used to choose TRCs coordinators and heads of school. School heads were purposively selected based on their understanding of TRCs effectiveness and accessibility. TRCs coordinators were chosen due to their proximity to TRCs. Ethical issues were settled as authors managed to solicit research permit from relevant officials in Biharamulo District. Biharamulo District was selected after claiming that teachers in the same district were found to be weakly prepared for teaching students in schools (School inspectors' reportWestern lake zone, 2015). Table 1 presents sample sizes of respondents.

Table 1: Sample size

\begin{tabular}{|l|l|l|l|}
\hline Respondents & Population & Sample size & Technique \\
\hline Head of schools & 18 & 10 & Purposive sampling \\
\hline Teachers & 630 & 63 & Systematic random sampling \\
\hline TRCs coordinators & 3 & 3 & Purposive sampling \\
\hline Total & $\mathbf{6 5 1}$ & $\mathbf{7 6}$ & - \\
\hline
\end{tabular}

(Source: Researchers, 2019)

The sample size was 76 respondents. It consisted of 3 TRCs coordinators, 10 heads of schools and 63 teachers. The Likert-type questionnaire, ranging from disagree to agree, was administered to sixty-three (63) teachers. Ten (10) school heads were subjected to Focus Group Discussions (FGDs), whereas three (3) TRCs coordinators were interviewed. School heads and TRCs coordinators were selected because they are expected to have more significant insights regarding teachers' involvement in TRCs. Both quantitative data and qualitative data were concurrently collected. The quantitative data from questionnaires were analysed by using descriptive statistics (percentages, frequencies), while the qualitative data from the FGDs were analysed through thematic 
techniques. Then, qualitative findings were mixed with quantitative results during data interpretation. According to Creswell and Plano Clark (2007), research based on qualitative methods is reported to be interpretive research. Hence, researchers interpreted the meaning of coded data as obtained from the interviews to the existing literature, the theory used in this study and researchers' experience.

\section{RESULTS AND DISCUSSION}

This study aimed to examine the perceptions and use of services provided by teachers' resource centres by secondary school teachers in Biharamulo District. The first objective was to assess secondary school teachers' perceptions of TRCs in Biharamulo District. The second objective was to establish secondary school heads' role in facilitating access and use of TRCs in Biharamulo District by teachers under their supervision. The third objective was to identify factor(s) that hinder secondary school teachers' attendance at TRCs in Biharamulo District. Quantitative data were collected by questionnaire, whereby a three-point Likert scale was used. An individual participant was required to respond to a series of statements in the questionnaire by indicating whether he/she agrees (A), or is neutral (N) or disagrees (D). These data are presented by descriptive statistics: percentages, frequencies and tables. Qualitative data were collected by interviews and FGDs. They are analysed into themes that emerged during the discussions. The qualitative data supplement questionnaires data in this study.

\subsection{Teachers' perceptions of the TRCs}

This section presents the perception of teachers towards TRCs. The themes obtained are: TRCs are perceived to improve teachers in teaching and learning, TRCs focused on primary school teachers, TRCs operates under insufficient resources, and teaching experience is enough rather than TRCs. Table 2 presents the responses on the perceptions of the TRCs.

Table 2: Teachers' perceptions of the TRCs

\begin{tabular}{|l|l|l|l|}
\hline \multirow{2}{*}{ Item } & Level of Agreement & Neutral & Agree \\
\cline { 2 - 4 } & Disagree & $1(1.6 \%)$ & $60(95.2 \%)$ \\
\hline TRCs improve teachers' effectiveness & $2(3.2 \%)$ & $2(3.2 \%)$ & $53(74.2 \%)$ \\
\hline TRCs were built to help primary school teachers & $8(12.6 \%)$ & $1(1.6 \%)$ & $7(11.1 \%)$ \\
\hline TRCs operate with insufficient resources & $55(87.3 \%)$ & $2(3.2 \%)$ & $4(6.3 \%)$ \\
\hline My teaching experience is sufficient & $57(90.5 \%)$ & \\
\hline
\end{tabular}

Field data, 2019

\subsubsection{Perceived as helpful in improving teachers' teaching efficiency}

As Table 2 shows, most teachers 60(95.2\%) perceived the TRCs services as quite helpful in improving teachers' teaching effectiveness. The results from questionnaires concurred with findings in Focus Group Discussions (FGDs), where school heads perceived TRCs services as helpful in improving teachers' teaching effectiveness. They added that TRCs offer all components necessary for enhancing teachers' techniques and profession. One of the school heads said:

"Despite that they are located in distant places from secondary schools, the three TRCs in the district are meant to support teachers in their profession" (Head of school 7).

The respondent meant that the TRC improves teachers' teaching techniques and work performance as a whole. The statement concurs with findings of the previous studies by Qvist and Omar (1996) and Giordano (2008), which found that the TRC develop teachers' profession through its in-service training programmes.

\subsubsection{Perceived as an under-resourced institution}

Many teachers, 55(87.3\%), and school heads from $5(83.3 \%)$ FGDs out of 6 FGDs perceived the TRC as an under-resourced institution. They claimed that the government put less emphasis on the centres in terms of the little fund allocated to centres. Indeed, the government's programme known as the Education Sector Development Programme (ESDP) aimed at providing teacher training and professional development facilities including the rehabilitation and utilisation of teachers' resource centres (URT, 2008). ESDP intended to equip TRCs with adequate resources to improve teachers' professional development and teachers' work performance. Despite the ESDP plan, the TRCs continue to operate under inadequate resources. The heads of school advised that the government solicit the support of donors and NGOs to enable the TRCs realise their mission and vision. For instance, one head of school reported:

It is impossible for the government to effectively and adequately equip TRCs with resources on its own. A partnership between different stakeholders is needed for the government to effectively develop teachers through these centres (head of school 4).

This finding signifies the need for collaboration between the government and other non-governmental institutions in developing and facilitating the TRCs to deliver intended services. The lack of adequate facilities in TRCs means that the quality of education given by the centres is questionable. Hardman et al (2009), Komba and 
Nkumbi (2008) agree that there are inadequate and un-coordinated in-service services at TRCs in Tanzania, making teachers outdated and ineffective in facilitating teaching and learning. Therefore, the government should seriously put emphasis on TRCs making them capable of equipping teachers with new techniques, exposure and networks.

\subsubsection{Perceived as for the territory of primary school teachers}

The majority 53(84.2\%) of teachers, and many heads of schools from $6(100 \%)$ FGDs believed that TRCs were specifically built for helping primary school teachers, not secondary school teachers. Heads of school thus said that they seldom talk and advise secondary school teachers to attend and use the TRC services; for this reason, one of school heads said:

"First of all, I never heard my district secondary education officer and heads of school talking about TRCs. What I know is that such resource centres are there to support primary school teachers in need of upgrading their education levels, not secondary school teachers; that is why I don't even motivate my staff to visit those centres" (School head 2).

The heads of school said that they put more emphasis on school development issues and teaching process by using available resources at school rather than improving teachers' skills through TCRs.

\subsubsection{Perceiving themselves as too experienced to need TRC services}

Participants were asked whether they felt themselves too experienced to need the TRC services. The majority of teachers, 57(90.5\%) disagreed with the statement. That is, they felt that they were not experienced enough, and hence, they needed services offered at the TRCs to make them teach students in secondary schools effectively. They also recognised that the TRCs would help them to network with their colleagues, which was very important to them. A sample of such views is this one from a head of school in an FGD:

"Teaching experience is very important but has nothing to do with necessary adjustments required for teachers to competently teach during this era of ever-changing needs caused by globalization and change in science and technology" (School head 9).

The statement contradicts Dennis's (2001) observation that experience is a thing that makes one a good teacher and a vital element in discovering what works in education.

Although there is strong evidence that teacher effectiveness and experiences increase sharply after the first few years of teaching (Kain \& Singleton, 1996 cited in Darling-Hammond, 2003), less competent teachers have an opportunity to develop their skills at TRCs (MacNeil, 2004). Even for experienced teachers, the world is everchanging, which means that teaching methods have to be updated.

For instance, learning institutions currently switch to teaching and learning through e-learning (ICT) to counteract COVID 19 anti-gathering rules. One of the factors which hinder provision of online learning during COVID 19 in Tanzania is lack of expertise and exposure in ICT, which the TRCs could solve. If teachers were conversant with ICT could conduct teaching and learning effectively through e-learning. TRCs could provide teachers training on how to teach and learn using ICT technologies which is a new phenomenon in their context.

\subsection{The role of school heads in promoting the TRC's access and use}

School heads are bound to administrative and instructional roles in their respective schools. They should ensure improved teachers' attendance at TRCs (Giordano, 2008; Burton, Carper \& William, 2011) to help teachers become more effective in their jobs. Heads of school play a major role in the success of TRCs by encouraging staff under them to attend the centres and gain the required knowledge in facilitating teaching and learning. In this backdrop, the second specific objective set out to explore the role of secondary school heads in promoting teachers' attendance at TRCs in Biharamulo District. The data collected by questionnaires are presented in tables, whereas the data from FGDs and interview are presented in themes and verbatim. Table 3 shows the role of school heads in promoting teachers' attendance at TRCs.

Table 3: The role of school heads in promoting teachers' attendance and use of TRCs

\begin{tabular}{|l|l|l|l|}
\hline \multirow{2}{*}{ Item } & \multicolumn{2}{|l|}{ Level of Agreement } \\
\cline { 2 - 4 } & Disagree & Neutral & Agree \\
\hline Organizing study trips for teachers to the TRC & $57(90.5 \%)$ & $2(3.2 \%)$ & $4(6.3 \%)$ \\
\hline $\begin{array}{l}\text { Inspiring teachers to acquire new and effective ways of } \\
\text { teaching at the TRC }\end{array}$ & $57(90.5 \%)$ & $2(3.2 \%)$ & $4(6.3 \%)$ \\
\hline $\begin{array}{l}\text { Encouraging teachers to borrow books and teaching aids } \\
\text { from the TRC }\end{array}$ & $55(87.3 \%)$ & $1(1.6 \%)$ & $7(11.1 \%)$ \\
\hline Insisting teachers' regular attendance at the TRC & $63(100 \%)$ & $0(0.0 \%)$ & $0(0.0 \%)$ \\
\hline Allowing teachers to share knowledge and skills at the TRC & $57(90.5 \%)$ & $2(3.2 \%)$ & $4(6.3 \%)$ \\
\hline
\end{tabular}

Field data, 2019

4.2.1 Heads of school's organisation of teachers' study trips to the TRC

Table 3 indicates that most teachers, 57(90.5\%) responded in questionnaires that school heads did not organise 
field trips to TRCs. The questionnaire findings match findings from FGDs and interview with heads of school. They equally stated that heads of school neither organised study trips for teachers to TRCs nor motivated teachers to acquire new and effective teaching methods from TRCs. They actually thought that the TRC was not intended for secondary school teachers but primary school teachers. Republic of Kenya (1988 as cited in Wanzare \& Ward, 2000) stated that school heads need to organise study trips for teachers to TRCs so that teachers can get current information about their profession, conduct demonstration of lessons, develop teaching aids from local materials, conduct studies on local educational needs and disseminate information on curriculum innovations.

\subsubsection{Heads of school's insistence that teachers share knowledge and skills at the TRC}

As Table 3 indicates, the majority of teachers, 57(90.5\%) disagreed with the item that school heads insist on teachers' sharing of knowledge and skills with other teachers at the TRC. When we asked why they did not insist on their teachers' attendance at TRCs for interacting and sharing experience with other teachers from other schools, they reported that they did not allow them to attend TRCs as they were aware of inadequate resources at the centres. They held that the centres were not intended for secondary school teachers.

Results from interview with TRCs coordinators revealed that very few teachers usually attended strategically planned programmes to equip them with requisite skills and teaching capabilities. One TRC coordinator attested to this in the interview:

"I have been a TRC coordinator for about 6 years to date. I usually announce and call upon teachers to attend programmes designed for them. However, I'm always astonished because only a fraction turns up at the centre for programmes" (TRC coordinator 3 ).

This implies that school heads seldom encourage teachers to share knowledge and skills at TRCs. Sharing knowledge and information quickly diffuses innovations among teachers from different schools; hence, it improves the teaching and learning process (Smith \& Wohlstetter, 2001). To improve teacher professionalism, teachers need to constantly update their skills to advance their teaching methodology with the support of their leaders. This is supported by Hassel (1999), who considered professional development as the process of improving staff skills and competencies needed to produce outstanding educational results for students. That is, teacher skills can be improved by allowing the sharing routine between teachers from one school with teachers from another school. Therefore, heads of school should support and encourage their staff to attend workshops and seminars organised by the TRC. Sigilai and Bett (2013), support that teachers need to be encouraged to develop lifelong reading habits and skills which in turn support their own self-development. They advise school heads to enable their staff to benefit from services offered by the TRCs effectively.

4.2.3 Heads of school's encouragement of their staff to borrow teaching and learning resources from the TRC

As shown in Table 3, majority of teachers, $55(87.3 \%)$, held that school heads seldom encouraged them to borrow textbooks and teaching aids from the TRC. This finding concurs with Phili (2006) who found that teachers failed to borrow textbooks from TRCs thus libraries in schools are not well equipped, having inadequate and shallow books. That is, most schools lack enough textbooks and other teaching and learning materials. Hence, the teaching and learning resources need to be borrowed from equipped TRCs. The interview results with TRC coordinators indicated that teachers inadequately use the available resources at the TRC. For instance, one TRC coordinator narrated:

"I personally agree that very few teachings and learning aids are available at this centre.

What I know is that though very few, their importance cannot be ignored. Therefore, teachers are highly expected to come and borrow these available resources so as to aid in the teaching and learning processes" (TRC coordinator 1).

This finding is reaffirmed by findings from Temu, Malmberg and Lindhe (2004) who found that school heads inadequately encouraged teachers to borrow books from the TRCs. They found that only 18 teachers borrowed books per month and only 16 read at the TRC library per week. Therefore, heads of school need to motivate, support and ensure that teachers solicit required teaching and learning resources, and use them when teaching.

4.2.4 Heads of school's insistence on teachers' regular attendance at the TRC

As noted in Table 3, all teachers 63(100\%) disagreed with the statement "heads of school encourage teachers to regularly attend at the TRC for their professional development". This finding was enriched by heads of school's views from FGDs. One of school heads, for instance, commented:

"I usually conduct meetings, particularly during the tea break. Nonetheless, I have never encouraged teachers to attend TRCs for their professional development. What I have been telling my teachers is to prepare schemes of work, lesson plans and to teach students as directed by the government. I mean, implementing the student-centred method and practising competence-based approaches" (Head of school 7).

The comment implies that secondary school heads lack knowledge of the use of the TRC in training 
teachers, no wonder they seldom insist on teachers' attendance at TRCs for career development. Some might be even denying their teachers permission to attend the centres. Another head of school also commented in FGD:

"It is obvious that none of us is bothering insisting that teachers attend the TRC. To me, it has been a long since I heard about the issue of the TRC. Thus, it becomes difficult to react to the information. I think the TRC is forgotten in this district. As head of school, I must be first trained in the TRC for me to encourage teachers to attend TRCs for their professional development" (School head 5).

That comment suggests that heads of school do not promote access and use of the TRC among staff under their supervision. This implies that heads of school lack knowledge of the vital role that the TRC may play in enhancing teaching and learning in their schools. Therefore, sensitisation about the role of the TRC in developing in-service teachers' career is needed among secondary school heads in Tanzania. Ribchester and Edwards (1998) found that partnership between teachers from the rural schools and those from the urban schools increased both sides' performance in the study area. Thus, teachers with new skills and good mastery of content deliver quality instructions in the classrooms.

\subsection{Factors that hinder the attendance of teachers at the TRC}

The third specific objective set out to identify factors that hinder secondary school teachers' attendance at the TRC in Biharamulo District. Table 4 presents findings for objective three.

Table 4: Factors hindering the attendance of secondary school teachers at the TRC

\begin{tabular}{|l|l|l|l|}
\hline \multirow{2}{*}{ Item } & \multicolumn{2}{l|}{ Level of Agreement } \\
\cline { 2 - 4 } & Disagree & Neutral & Agree \\
\hline Lack of modern resources and experts at the TRC & $4(6.3 \%)$ & $2(3.2 \%)$ & $57(90.5 \%)$ \\
\hline Insufficiency of fund and support to teachers at the TRC & $2(3.2 \%)$ & $1(1.6 \%)$ & $60(95.2 \%)$ \\
\hline Distant locations of TRCs from the working stations & $8(12.6 \%)$ & $2(3.2 \%)$ & $53(84.2 \%)$ \\
\hline Lack of teacher's commitments & $8(12.6 \%)$ & $2(3.2 \%)$ & $53(84.2 \%)$ \\
\hline
\end{tabular}

Field data, 2019

4.3.1 Lack of modern resources and experts at the TRC

As shown in Table 4, most teachers 57(90.5\%) responded that the lack of modern resources and experts at TRCs is among the factors that discourage teachers from attending the centres. Heads of school through FGDs revealed that TRCs did not have competent experts to train teachers on ICT issues such as computers and powerpoint presentation. They reported further that they did not allow teachers to attend the centres because there was no new knowledge they could gain therein. One head of school reported:

"You know that TRCs in our district lack new resources and modern technologies. It seems that TRCs have been forgotten; the government neither put emphases on nor employs IT experts for the centres. There are no computers or installed internet systems...no one would like to waste his/her time for attending these centres" (Head of school 2).

The finding implies that TRCs in Tanzania need to be equipped with modern resources and need to employ experts teaching and learning with ICT. Maclsaac (1996) observes that the availability of resources in schools improves teaching and learning, hence higher students' achievement. However, Tanzanian secondary schools, particularly community secondary schools, experience acute shortage of teaching and learning resources (Mtitu, 2016). Thus, designated TRCs in the district need to be equipped with adequate modern resources to enable teachers from different schools to access necessary materials for improved delivery of quality instructions.

\subsubsection{Insufficiency of fund and support for teachers to attend the TRC}

As Table 4 shows, most teachers 60(95.2\%) reported the lack of fund as a limiting factor for teachers to attend TRCs. This finding is reaffirmed by Giordano (2008) who found that making teachers cover expenses from their own pockets discourage teachers from attending resource centres. That is, the monthly salaries of teachers hardly cover all of their critical needs. In this regard, they usually do not have the fare for the TRC visits. Similarly, heads of schools said in the interview that the government has not set aside the fund for fare for teachers who attend TRCs. That is, disbursement of funds to schools does not include a certain amount of money that could save as fare for teachers to attend TRCs. However, Darling-Hammond (2003) suggests that school budgets need to contain financial supports to attract, retain, and support the continued learning of teachers. That is, the government should ensure that school budgets are extended to cover necessary supports and fare for teachers to attend TRCs for improved delivery of quality instructions.

\subsubsection{Distance to and from TRCs and teachers' commitments}

Many teachers, 53(84.2\%) reported that the long distance between the TRCs and the working stations, and the lack of teachers' commitment hindered their regular attendance at TRCs. In Tanzania, most TRCs are located in towns, whereas most schools are in rural areas; hence a few teachers can afford to attend the centres. Koda (2006) found that travelling long distances between schools and TRCs denied large groups of teachers an access to 
TRCs. Results from the interview with TRCs coordinators indicated that most teachers failed to attend TRCs due to long distances between their working stations and TRCs. One of TRC coordinators, for instance, said: "... and I have friends who are teachers, but when I ask them reasons for their absence from TRCs, their answer is always the long distance of the centres from their schools" (TRC coordinator 2).

The heads of school through FGDs added that teachers lack commitment to attend TRCs, which is a prerequisite for their professional development. One of school heads said:

"What I think is that teachers' readiness is crucial. Even after being encouraged, teachers need to be ready by themselves to attend the TRC. The same readiness, which makes most teachers engage in moonlighting activities, is needed in attending the TRC. Teachers should show commitment in seeking skills from the TRC” (School head 9).

The finding implies that teachers' commitment can overcome obstacles such as distance between the TRC and the working stations, lack of funds, and lack of encouragement. Teachers need to take courage and be committed to developing their careers by attending the TRCs in the district.

\section{CONCLUSION}

After data analysis and interpretation of the findings, it can be concluded that most of secondary school teachers perceive the TRC as useful in professional development. However, most teachers believe that the TRC is primary school teachers' territory rather than involving secondary school teachers. The study further found that most school heads neither encouraged nor inspired teachers to attend at the TRC to gain and share skills and borrow books and teaching-learning resources. Likewise, school heads rarely organised study trips for teachers to attend TRCs for their professional development and improved instruction. Furthermore, teachers' attendance at the TRC is challenged by the lack of funds for fare, lack of school heads' encouragement and inspiration, long distance between the working stations and the TRCs, and lack of teacher's commitments to attend the TRC for career development.

The study recommends further research on the role of the TRC in training in-service teachers. The study also suggests that the Ministry of Education, Science and Technology should equip the TRC with modern teaching and learning resources to enable it to meet its objective of training in-service teachers. The study also recommends reminding school heads of their responsibility to inspire and encourage teachers under their supervision to attend the TRC for their professional development regularly.

\section{REFERENCES}

Biharamulo District Council Report. (2018). Educational status report in Biharamulo District (Brochure). Biharamulo, Author.

Binde, A. L. (1999). Teachers' resource centres. Baseline study in Tanzania. Dar es Salaam. Dar es Salaam University Press.

Burton, L., Carper, K. C., \& William, V. (2011). The sociological of educational supervision and evaluation. Journal of Cross-Disciplinary Perspective in Education, 4 (1), 24-33.

Compoy, R.W. (1997). Creating effective instruction models in professional development school. Prof. Educ. J. Res, $19(2), 32-42$.

Creswell, J. W., \& Plano Clark, V. L. (2007). Designing and conducting mixed methods research. Thousand Oaks, CA: Sage.

Darcos, X. (2003). Les réseaux d'écoles primaires: dossier de presse. Paris: Ministère de la Jeunesse, de l'Éducation nationale et de la Recherche, 5 Novembre 2003.

Darling-Hammond, L. (2003). Keeping good teachers: Why it matters and what leaders can do. A journal of Educational Leadership, 60 (8), 6-13.

De Grauwe, A., \& Carron, G. (2001). Resource centres as close-to-school support service. For IIEP training workshop on reforming school supervision for quality improvement, Grenada, 16 to 24 August 2001. Paris: IIEP-UNESCO

Dennis, N. (2001). Teaching and learning in engineering classroom. University of Florida: Workshop, 16 to 17 February 2001

Gaible, E., \& Burns, M. (2005). Using technology to train teachers: Appropriate use of ICT for teacher professional development in developing countries. Washington: The World Bank.

Giordano, E. A. (2008). School clusters and teacher resource centres. Paris: United Nations.

Guskey, T. R. (2000). Evaluating professional development. Thousand Oak: Corwin Press.

Hardman, F., Abrishamian, N., Chediel, R.W., \& Tibuhinda, A. (2009). A review of teacher education in Tanzania and the potential for closer links between PRESET and INSET: A report produced in support to the ministry of education and vocational training in developing an INSET strategy 2008-2013. Tanzania, Dar es Salaam. 
Hassel, E. (1999). Professional development: Learning from the best. Northcentral regional educational laboratory. Illinois: Oak Brook.

Khan, A. (2015). Head teachers' beliefs and practices about teaching and learning in Pakistani public schools. Creative Education, 6, 2299-2312. http://dx.doi.org/10.4236/ce.2015.622237

Kimaro, D. (2005). Development through the use of TRCs in Tanzania: A case study of Kibaha District. Unpublished Master's Thesis. University of Dar es Salaam, Tanzania.

Kisuda, A. (2005). Functions, organisations, leadership and financing of TRCs: A case study of Singida District. Master's Thesis. University of Dar es Salaam, Tanzania.

Knamiller, G., Jain, P., Khatete, D., Gibbs, W., Welford, G., Fairhurst, G., \& Wiegand, P. (1999). The effectiveness of teacher resource centre strategy. London: Department for International Development Education Research.

Koda, M. G. (2006). Effectiveness of teachers' resource centres: A case study of TRCs in Kilimanjaro and Mbeya regions in Tanzania. Unpublished Doctoral Thesis, University of Dar es Salaam, Tanzania.

Koda, M. G. (2012). Teachers' resource centres: A strategy for secondary school teachers' professional development in Tanzania. Journal of Education, Humanities and Sciences, 1(2), 78-92.

MacIsaac, D. (1996). The critical theory of Jurgen Habermas: Retrieved on 10th February 2021 from: http://www.physics.nau.edu/ danmac.

MacNeil, J. (2004). School and cluster-based teacher professional development: Bringing teacher learning to the schools. EQUIP1 Working Paper No. 1. Washington, DC: USAID.

Ministry of Education and Culture-MoEC. (2000). Teacher education department report: Zonal TRC workshop: Klerruu Teachers' College, 5 to 9 June 2000.

Mirambo, D. N. (2007). Management of teachers' resource centres in improving primary school teachers' classroom performance (Unpublished Master's Thesis). University of Dar es Salaam, Tanzania.

Msuya, A. S. (2015). Prospects and challenges of teachers' resource centres in teachers' professional development in Mbulu District, Tanzania (Unpublished MA Dissertation). Open University of Tanzania, Dar es Salaam.

Mtitu, E. A. (2016). Challenges of top -down curriculum on the quality of classroom instructional practices: Voices from the bush. Journal of Issues and Practices in Education, 8 (1), 50-68.

Mushi, P. S. D. (2003). Teachers' resource centres: Theory and practice. Dar es Salaam: Dar es Salaam University Press.

Ndikumwami, M. (2013). Investigation of challenges that face teachers in improving teaching performance in primary schools: A case of Dodoma Municipal council (Unpublished MA Dissertation). Open University of Tanzania, Dar es Salaam

Phili, J. (2006). A perspective of challenge facing basic school teacher training, recruitment and quality in Zambia, University of Zambia.

Pollard, A., \& Tann, S. (1993). Reflective teaching in the primary schools. London: Cassell.

Qvist, K., \& Omar, B. (1996). Teachers' resource centres: Regional workshop on TRCs. Dar es Salaam: Ministry of education and culture.

Ribchester, C., \& Edwards, W.J. (1998). Co-operation in the countryside: Small primary school clusters. Journal of Educational Studies, 24(3), 281-294.

Richards, C. (1996). Microcentres for rural schools in Chile: Centres for learning with extension. In: S. Schaeffer and R. Govinda. Innovations in school-based management: Towards a new framework for school management, creating stronger partnerships for better education. Paris: UNESCO.

Sabaya, W. (2011). Teachers as springboards for quality education promotion. http://sabayawilliam.blogspot.com (Accessed on March 7, 2016).

School inspectors' report-Western lake zone. (2015). Inspection of secondary schools: General and pedagogical documents (Brochure). Kagera Region, Author.

Sigilai, M. R., \& Bett, C. J. (2013). Effectiveness of head teachers' leadership styles on the management of public primary school curriculum implementations in Bomet county. Journal of Emerging Trends in Educational Research and Policy Studies, 4 (2), 375-382.

Smith, A. K. \& Wohlstetter, P. (2001). Reform through school networks: A new kind of authority and accountability. Journal of Educational Policy, 15(4), 499-519.

Sumra, S., \& Rajani, R. (2006). Secondary education in Tanzania: Key policy challenges. Dar es Salaam: Hakielimu.

Temu, E.B., Malmberg, K., \& Lindhe, V. (2004). SIDA support to teacher education in Tanzania (1997-2002: Department of democracy and social development. ISSN: 1401-0402). http:// www.sida.se/publications

United Republic of Tanzania-URT. (2008). The education sector development programme (ESDP) 2008-2017: Ministry of Education and Vocational Training. Dar es Salaam, Tanzania.

Wanzare, Z., \& Ward, K. L. (2000). Rethinking staff development in Kenya: Agenda for the twenty-first century. 
International Journal of Educational Management, 14(6), 265-275.

Weiner, B. (1972). Attribution Theory, achievement motivation, and the educational process. Review of Educational Research, 42(2), 203-215. 